\title{
SPECIAL ARCHITECTURAL REQUIREMENTS OF EDUCATIONAL BUILDINGS
}

\author{
Péter KOVÁCS, ${ }^{1}$ Tamás MOLNÁR, ${ }^{2}$ Balázs KÓSA ${ }^{3}$ \\ University of Pécs, Faculty of Engineering and Information Technology, Pécs, Hungary \\ ${ }^{1}$ kope.hun@gmail.com \\ ${ }^{2}$ tmolnar@mik.pte.hu \\ ${ }^{3}$ kosa.balazs@mik.pte.hu
}

\begin{abstract}
In the decades elapsed since the construction of the majority of educational buildings in Hungary, there have been various social, economic, and demographic developments that affect the utility of existing infrastructure. These changes present special requirements - those not met by existing, often heritage buildings - setting a challenge to both architects and decision makers. The aim of this study is to analyse the various aspects of these developments and reflect on the extant architectural framework of education, serving as a basis for further investigations on ways architecture can enhance the learning environment.
\end{abstract}

Keywords: built heritage, educational buildings, rehabilitation.

\section{Analysis of extant infrastructure}

The majority of educational buildings in Hungary were constructed in the mid to late 20th century, supplemented by earlier heritage buildings and a smaller number built following the change of system. Due to the age of this infrastructure, its development provides both architects and decision-makers with present and future challenges. The goal of this study is to review the current built environment of education and the change of requirements set by society.

This infrastructure, developed in the course of centuries is diverse not only due to the age, and thus contrasting qualities of these buildings, but also on account of their distribution. Different regions present a different outlook as a consequence of their economic standing and demographic history. Thus, having the goal of obtaining results that are of utility to architecture, a statistical analysis is of low practical value, as these differences prevent the formation of a unified overview.

The creation of a typology, as a result of a predetermined set aspects, and conducting the study on these types is a more efficient approach to this objective. The study will first summarise these aspects, being either factors directly affecting architecture or the underlying causes that affect society's expectations.

\section{Change of requirements and under- lying factors}

\subsection{Economic factors}

Of the factors affecting the architecture of educational buildings, economic factors are significant, as other factors - appearing as demands set by society - can only have an effect via some form of economic apparatus. These economic factors include the source and quantity of financial resources, the centralisation or decentralization of educational organization and the varying support of different forms of education.

It is also important to note the inequalities inflicted by these economic mechanisms that can negatively affect the built environment of disenfranchised communities and forms of education lacking social support. 


\subsection{Demographic effects}

The main driving forces behind the large scale establishment of new education facilities is demographic in nature. The extensive developments of post Second World War Hungary stem from urbanization, while post-socialist development was driven by suburbanisation. Besides demographics, the average age, social standing and ethnic composition of the regions and communities has also had an effect on the state of infrastructure.

\subsection{Didactics}

The underlying model of education in Hungary since the development of the protestant school model has changed little enough to preserve the utility of historic educational buildings - new types of institutions and schools employing alternative methods having developed their unique built environment [1]. These changes, however, do affect the quality of use of existing buildings.

In regard to architecture, the most tangible dimension of educational methods is the decrease of the average number of students in a class as a long term trend. Also changing is the time students spend in these buildings, and as a consequence, the demands for the quality and volume of social spaces within these institutions.

\subsection{Social requirements}

As a consequence of the factors discussed prior, there is an emerging need for educational buildings to not only act as spaces of teaching, but as a social space significant to both the students and the community, as exemplified by new facilities created in areas of suburbanisation, as a response to changes in the size and needs of the community.

\subsection{Thermal comfort and energy efficiency}

Energy efficiency is a key challenge concerning the long term sustainability of existing educational buildings. The long term economic benefit of state-of-the-art construction methods is, however eclipsed by the considerable up-front costs. As a result, renovation of existing buildings to meet this goal is the norm.

In addition to the need for sustainability, buildings are aggravated by ever evolving thermal comfort requirements. Both of these factors are intensified by the ongoing climate change, creating the need for advanced cooling, shading and ventilation solutions.

\subsection{Accessibility}

Society displays an ever growing need for educational spaces to become more accessible to those living with disabilities. The fulfilment of this need in existing buildings meets both physical and financial obstacles. In addition to providing access to the disabled, contemporary school architecture displays consideration for the different physical, mental and emotional attributes of students of different ages. Creating an open, accessible and integrated learning environment has social and financial benefits, reducing the need for specialised institutions.

\section{Typology and analysis}

\subsection{Historic and heritage buildings}

In regard to the aspects above, historic buildings constructed prior to the advancements of modern architecture can be thought of as a group, disregarding external, architectural differences. Their adaptation for current needs is encumbered by restrictions on heritage buildings, and often their position in dense historic urban fabric.

The higher maintenance costs of these buildings are offset by the high regard of society and the prestige of a historical campus. For this reason, in spite of their high upkeep costs, these buildings are seldom abandoned by educational facilities.

\subsection{Modernist educational buildings}

In Hungary, most modernist educational buildings were constructed in the decades following the Second World War. While buildings constructed during this period of urbanisation often utilize standardized plans -the architecture of the era is abound in innovation - in-deed, many of these type plans are adaptations of a previously successful design. [2] In comparison to earlier educational architecture, improvements were made in the use of natural lighting and ventilation, the morphology of educational and social spaces. Exemplary in this regard is the work of Kamill Kismarty-Lechner. (Figure 1.)

These buildings - as much of the architecture of the time period - lack high the regard of society that heritage buildings enjoy, and hence are often subject to unplanned reconstruction or modification, despite the possibility of a deliberate architectural approach highlighting and complementing their extant values. This sensitive approach characterises the reconstruction and expansion 


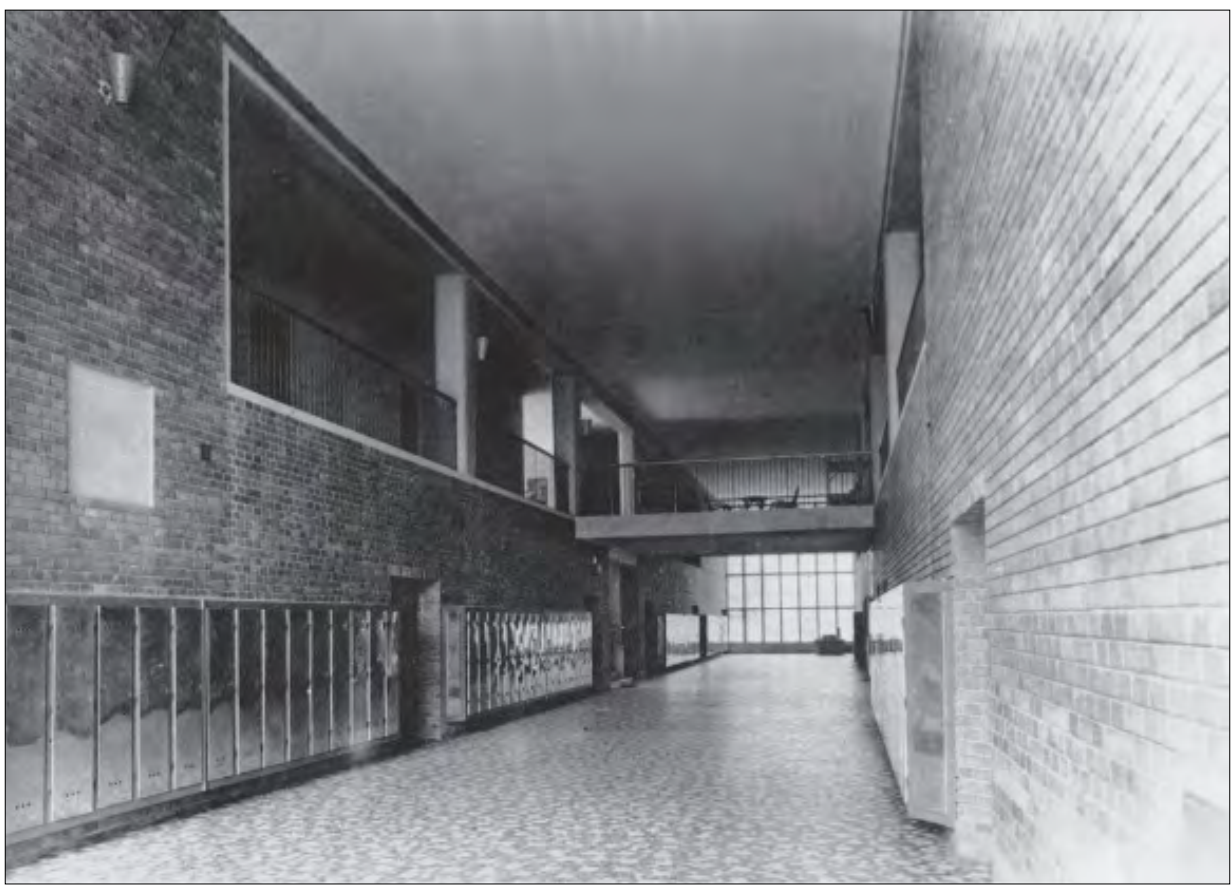

Figure 1. Kismarty-Lechner Kamill Kismarty-Lechner: Primary school in Budapest, Sodronyos st. 1955-1958. [2]

of Újvárostéri Primary School in Ózd, designed by Györgyi Csontos. [3]

\subsection{Social realist architecture}

The short-lived architectural period resulted in a relatively large number of educational buildings, owing to its coincidence with a large wave of urbanisation due to the development of heavy industry. The contemporary judgement of this period is debased by both its political connotations and its setback from developed modernist architecture. While this, together with the decay of regions of heavy industry, makes their ongoing utilization and rehabilitation difficult, it is important to note the accomplishments of the urban design of the era regarding the integration of educational buildings in the fabric of residential areas.

\subsection{Educational buildings from the 1990's onwards}

The main driving force behind construction of educational buildings following the socialist era was the demographic shift towards suburbanisation. There are several examples of architecture in Hungary of educational buildings that react creatively to challenges this shift presented, and the role of these buildings in the affected regions. Another hallmark of the contemporary approach is the deliberate re- gard for economy and sustainability on a local level. An example of these qualities is the school building in Pellérd, designed by Tamás Getto. [4]

\subsection{Adaptation of educational buildings}

In addition to the previous types marked by construction periods, there are cases where education takes place in buildings not designed for education, or the specific form of education, as a result of macro-economic considerations or the financial difficulties of the given institution. The consequence of this can range from the possibility of inventive architectural solutions making for a successful transition to an institution stymied by its inappropriate built environment.

On the other hand is the issue of reuse of former educational buildings. These structures, abandoned by their primary function are frequently left to decay, as their adaptation to a new function is, in most cases, impossible or not economically viable.

\subsection{Buildings of special or alternative edu- cation}

Special forms of education, such as institutions working with alternative educational methods, as well as special schools catering to the disabled or socially disadvantaged, benefit from a built environment which takes into consideration the particular needs of its students or teaching methods. 
[5] While these specialized buildings represent a small portion of educational architecture in Hungary, they can provide results of universal utility - owing to their sensitivity towards the needs of their users and the innovative methods used to cater to them. This is especially true for buildings of privately funded institutions where scarce financial resources did not present an obstacle towards this objective.

At the same time, as these institutions are outliers in the framework of educational organisation and funding, there are cases when - due to the lack of financial or social support for a given model of education, or the disenfranchisement of the institution's target population, these institutions remain at risk of inhabiting a less than optimal built environment.

\section{Conclusions}

As evidenced by the solutions reviewed in the study, most of the educational infrastructure can be sustained for the foreseeable future, provided the use of appropriate architectural approach, meeting present and future requirements.

The current trend in the reconstruction, alteration and expansion of these buildings favours macro-economic factors over careful analysis of local issues, therefore resulting in developments lacking the input of the architectural community The architectural impact of the inequality of financial resources is also perceivable. The cause and solution to this issue is socio-economic in nature, nevertheless it presents a challenge architecture has to overcome.

\section{Acknowledgement}

Supported by the ÚNKP-18-3.-I. New national excellence program of the Ministry of Human Capacities.

\section{References}

[1] Cságoly F.: Középületek. TERC Kft., Budapest, 2004. 65-83.

[2] Lantos E.: 1945 Utáni iskolatervezés Magyarországon. Típustervek és egyedi épületek. Művészettörténeti Értesítő, 63/2. (2014) 373-396.

[3] MIXA Stúdió. Ódzd - Újvárostéri iskola. (accessed: 2019 feb.15.)

https://www.mixastudio.hu/ujvarosteri-iskola/

[4] BME. Általános Iskola - Pellérd. (accessed: 2019. feb. 15.).

http://hazai.kozep.bme.hu/hu/altalanos-iskola-pellerd/

[5] Sanda I. D.: A reformpedagógiai irányzatok iskolaépítési törekvései. Iskolakultúra, 18/9-10. (2008) 129-142. 